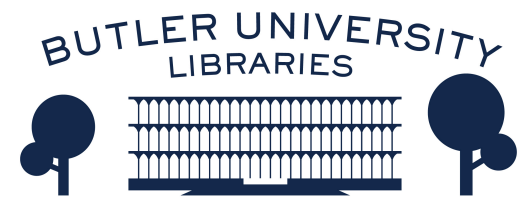

Journal of Hindu-Christian Studies

January 2009

\title{
Book Review: "An Encounter of Peripheries: Santals, Missionaries, and their Changing Worlds, 1867-1900"
}

Chad Bauman

cbauman@butler.edu

Follow this and additional works at: https://digitalcommons.butler.edu/jhcs

Part of the Religion Commons

\section{Recommended Citation}

Bauman, Chad (2009) "Book Review: "An Encounter of Peripheries: Santals, Missionaries, and their Changing Worlds, 1867-1900"," Journal of Hindu-Christian Studies: Vol. 22, Article 13.

Available at: https://doi.org/10.7825/2164-6279.1440

The Journal of Hindu-Christian Studies is a publication of the Society for Hindu-Christian Studies. The digital version is made available by Digital Commons @ Butler University. For questions about the Journal or the Society, please contact cbauman@butler.edu. For more information about Digital Commons @ Butler University, please contact digitalscholarship@butler.edu. 


\section{BOOK REVIEWS}

\section{An Encounter of Peripheries: Santals, Missionaries, and their Changing Worlds, 1867-1900. Marine Carrin, Harald Tambs-Lyche, New Delhi: Manohar, 2008, 386 pgs.}

\begin{abstract}
ENCOUNTER of Peripheries is so named because it analyzes the encounter of Scandinavian missionaries. "on the periphery of Europe" (9) with the adivasi Santals, who were marginal to the Hindu caste system and, in this period, "beyond the direct control of British India" (9). And indeed, one of the strengths of the book is the way in which it demonstrates that the Santals and their earliest missionary interlocutors from the Indian Home Mission to the Santals (IHM, est. 1868) were not so different as one might assume. For example, a sense of national identity was stirring, at this time, both among the Santals and in Norway, birthplace of the most dominant of the IHM missionaries, Lars Olaf Skrefsrud (b. 1840), and source of much financial support for the mission. Similarly, at the tail end of the $19^{\text {th }}$ century, Norway and "Santalistan" (as the missionaries preferred to call it) were not as yet divided by technological development-both had experienced the arrival of train travel in the same year, for example. Likewise, Christianity in both contexts was still in obvious ways influenced by and in conversation with the preChristian past, a fact not lost on Skrefsrud, who in answer to an ethnographic questionnaire from H. H. Risley explicitly linked the chief Santal bonga (spirit), Maran Buru, with the Scandinavian shape-shifting god, Loki (200). And finally, sexual mores in Norway and among the Santal were similar in significant ways; in both contexts, a considerable degree of latitude was given to pre-marital promiscuity, for example. For all of these reasons, the authors argue, Skrefsrud, who had been an apathetic believer at best before having a transformative religious experience while in a Norwegian prison, did not experience Indian life as "a civilized European confronted with the life of savages" (54). Rather, among the Santals he "confronted his own sinful past" (54).
\end{abstract}

Encounter of Peripheries is also particularly good at situating the views and behavior of the IHM missionaries in the context of broad social and theological trends in northern Europe. Long passages of the book are dedicated to providing historical background about Evangelicalism (and specifically Lutheranism), pietism, revivalism, the Haugean movement, the Grundtvigian movement, the Thrane movement, High ChurchLow Church controversies, etc., and demonstrating how the IHM missionaries were affected by them. The authors also reveal the ways in which the IHM missionaries were molded by their own vocational trajectories. Skrefsrud and his earliest collaborator, the Danish Hans Peter Börresen (b. 1825), began their work in India with the Gossner Missionary Society. After being dismissed by the Gossner mission amid rumored scandals, the two missionaries and their wives encountered Baptists in Calcutta, and upon their advice opened the Santal mission with Baptist Missionary Society support. Baptist support provided a stumbling block for many of the IHM's Scandinavian supporters, and Skrefsrud himself initially converted to the Baptist faith only to declare himself once again a Lutheran later in life. On the strength of these passages, I would recommend Encounter of Peripheries to anyone interested in the history of northern European, and particularly Scandinavian Christian missions (in India or elsewhere).

There are a number of problems with the text, however. First, while asserting the peripheral nature of the IHM missionaries in India, the authors suggest that to these Scandinavians, "as to most non-British, the Empire was simply there, part of a world order in which they were free to create their own projects...The Scandinavian missionaries were as much or as little part of the imperial agency as were artisans or prostitutes from various 
nations. Both were part of colonial dynamics, but not of the colonial project. They were there to realize their own" (346). It is certainly true that the IHM missionaries were neither colonial officials nor British, and this represents at least two degrees of separation from colonial power. Moreover, as has been well established by many authors, including Carrin and Tambs-Lyche, missionary values and ambitions were often at odds with those of the empire. That said, the authors of Encounter of Peripheries seem blind to the many ways that the missionaries benefitted from being significantly less peripheral to the empire than the Indians with whom they worked. The IHM missionaries, for example, used colonial power to shutter a number of liquor shops near their mission field in fit of teetotalism. Similarly, the mission was given supervision over colonial irrigation works during the 1874 famine, exposing thousands of impecunious Santal workers to missionary preaching, and leading to 1,600 conversions in that one year alone. In addition, several days after leaders of the subversive socio-religious Kherwar movement among the Santals promised to publicly consider Christianity and then just as publicly rebuffed missionary advances, Skrefsrud wrote to colonial authorities urging that they take severe and violent action against Kherwar partisans. In so many ways, then, the IHM missionaries were a significant part of "imperial agency" and how it was projected into the lives and minds of the Santals. And certainly the missionaries participated in the "civilizing mission" which was part and parcel of the "colonial project."

A second problem with the text is that it is inordinately focused on the European side of this ostensible encounter. As indicated above, we learn quite a bit about the Europeans who worked among the Santal, and the book even contains a one- to two-page biographical overview of nearly every important European (or American) who supported the mission or who interacted with the missionaries. But we learn disappointingly little about the Santals themselves, and even less about those Santals who become Christian. Of the Santal Christians, only half a dozen are given any significant space in the text, and these are almost entirely prominent pastors and under-acknowledged collaborators of the missionaries on various linguistic, translation, and ethnographic projects. From the text, then, we learn very little about the "changing world" of ordinary Santal Christians, how their lives and minds were changed, and how they responded to these changes, even though tantalizing (but unelaborated and underanalyzed) tidbits in the text suggest that information available could have supported this kind of analysis. Despite the ethnographic background of its authors, therefore, the text tells us little more about India and about Indians themselves than many other archive-based and missionary-focused mission histories.

A third problem with the text is organizational. The text reads as if it were a series of short essays, written individually over time, and then patched together later. Several chapters in the text have little internal cohesion, and contain sections which seem immaterial to the topic at hand. Moreover, the text ranges broadly, and occasionally lapses into historical tangents which are not carefully shown to be relevant to the theme of the book. Certainly it takes many metaphorical flapping butterflies' wings to constitute the necessary conditions for a (historical) tornado. But some flapping butterflies are more significant than others, and historians must discern which are worth mentioning and which, for the sake of the story, are not. Often the historical data provided by Encounter of Peripheries do not enrich the narrative so much as they obstruct and stall it. The overall effect of these organizational problems, therefore, is a frustrating absence of narrative momentum and a loss of chronological clarity.

The best sections of the text come in an Epilogue (part of the last chapter on "Tradition and its Reinvention"), where for ten short pages the authors begin to engage their topic from a more theoretical perspective. It is clear from this short section (the reader wishes it were longer) and from the text as a whole, that the IHM archives are a treasure-trove of historical and ethnographic information. The authors of Encounter of Peripheries are therefore to be thanked for opening up a source of raw material that linguistic issues would prevent many of us from accessing, and for pointing the way forward for future researchers.

Chad Bauman

Butler University 